\title{
Revisiting the Economic Growth-Welfare Linkages: Empirical Evidence from Nigeria
}

\author{
Richardson Kojo Edeme ${ }^{1}$ \\ 1 Department of Economics, Faculty of the Social Science, University of Nigeria, Nsukka, Nigeria. \\ Email:richard.edeme@unn.edu.ng
}

\begin{abstract}
This study aims at ascertaining the relationship between welfare and economic growth in Nigeria, capturing both economic and environmental welfare. Nitrous oxide emission and Carbon dioxide emission in Nigeria are used to capture environmental welfare while government education expenditure, per capita health expenditure and per capita income are used to capture economic welfare. Using quarterly data spanning 1999-2016 and employing the cointegration analysis as well as the Ordinary Least Squares (OLS) estimation technique, the study found that a long-run relationship exists between economic growth and welfare in Nigeria. It also found that both environmental and economic welfare significantly affect economic growth in Nigeria.
\end{abstract}

Keywords: Economic growth, Welfare, Per capita health expenditure, Per capita income, Economic welfare, Environmental welfare, Nitrous oxide emission, Carbon dioxide emission.

Licensed: This work is licensed under a Creative Commons Attribution 4.0 License.

\section{Introduction}

In economics, it is argued that social welfare should be in accordance with the growth level of a country. Thus, economic development will be undermined if the authorities fail to provide enough welfare for the people as growth occurs (Sardar, Islam and Clarke, 2002, Awan, 2015). The relationship between economic growth and well-being has a long and complex linkage or inter-connection, especially linking them with sustainable development. Perhaps, this spur the seminal work of the World Commission on Environment \& Development (WCED) which linked development with three sustainable indices, decomposed into: environment, economic and social. Arising from this, there was paradigm shift in the definition of economic development to sustainable development which is defined as a process that meets present needs without compromising the ability of future generations to meet their own needs. The WCED importantly attaches strong emphasis to issues of equity, especially the goal of alleviating poverty in societies where majority of of the citizens benefit from the opportunities provided by the development process (Neumayer, 1999).

A contrasting perspective on the challenge of reconciling growth, social welfare and the needs of future generations was however put forward by Meadows, et al, on their prediction that natural resource depletion and environmental degradation would lead to an irreversible collapse of the global economy by the early $21^{\text {st }}$ century. Unlike the WCED, Meadows, Randers and Meadows (2004) present straightforward argument that because economic growth is the perceived driver behind resource depletion and environmental degradation, the consideration of economic growth should be embedded in the objective in the attainment of sustainability. This view has however been criticized on the premise that economic growth is fundamental to the improvement of welfare and future generation and as such policies that retards growth should be treated as unworkable and detrimental (Abramowitz, 1981). The effect of economic welfare development on economic growth in recent times is emphasized on the growth theory (Romer 1990, Balami, 2006). An interesting idea in their work was that, in the long-run, output per unit of input could increase even when inputs were exhaustively accounted for. Technically, advanced human capital and a growing knowledge base appear to be 
part of this wellspring of growth. An implication of Lucas hypothesis on economic welfare is thus; associated with investment in knowledge as a productive resource. This underscores the fact that economic processes which create and diffuse new knowledge are essential to shaping the growth of nations (Balami, 2006, Adelakun, 2011).

The general proposition that economic growth is good for the environment has been justified by the claim that there exists am empirical and some measures of environmental quality. It has been observed that when income is high, there is increasing environmental degradation up to a point after which environmental quality improves. That is, poor countries cannot afford to emphasize amenities over material well-being. Consequently, in the earlier stages of economic development, increased pollution is regarded as an acceptable side effect of economic growth. However, when a country has attained a sufficiently high standard of living, people give greater attention to environment legislation, new institutions for the protection of the environment, economic and social welfare. The wellbeing of the current generation depends on both the flow of consumption it receives during its own lifetime. In another strand, it has also been contended that economic growth which necessarily leads to an enhanced quality of life and improved high-income societies is also problematic from a social science perspective. As argued by Howarth, Rosenwald and Rosenwald (2012) eventhough economic growth provides a mix of benefits and costs in terms of its contribution to human welfare, evidence have shown that in most developing countries, growth have been able to provide material goods that can just satisfy urgent needs given that institutions that allocates goods and services to the poor are weak and in some cases, non existence. In developing societies, however, growth has generated complex set of social and environmental costs.

However, recent literature has contrasted economic welfare, described as the ultimate goal of the growth process, with economic growth described as an imperfect proxy for more general welfare, or as a means toward enhanced economic welfare. This debate has broadened the definition and goals of growth, but still need to expose the important interrelations between economic growth and welfare. Moreover, the widespread clamour for immediate draconian action to reduce the danger of global warming is an unjustifiable diversion of attention from the more serious environmental problems facing developing countries. Resources constraints do not constitute limits to growth, and the likely economic damage done by climate change would be a negligible proportion of world output (OECD Council Meeting, 2015). The loss of welfare of the population in developing countries today as a result of inadequate access to safe drinking water and sanitation, renewable energy consumption, carbon dioxide emission and natural resource depletion is an indication that growthwelfare relationship should be given priority in order to meet the growth needs of the present and future generation. This paper contributes to existing literature by developing new empirical strategy to estimate the linkage between economic growth and welfare in Nigeria using different measures of sustainable development indices.

\section{Materials and Materials}

The data set for this study consists of secondary time series spanning 1999 through 2016. The variables under consideration are: The variables are obtained from the World Bank's World Development Indicators (2015) and Central Bank of Nigeria Statistical Bulletin (2016). From the foregoing, it is established that there are several theories on both economic growth and welfare. However, the theoretical framework of the study is anchored on the traditional welfare theory, neoclassical welfare theory. Further to Verfaillie and Bidwell (2000) where eco-efficiency was a key concept, this study brings together the economic and ecological variables which are necessary for economic and socio sustainability.

This study adopts the multiple regression models, This is essential in this is to capture the individual impact or effect of each independent variable on the dependent variable as well as determining the rate at which they (the independent variables) affect the dependent variable.

In order to examine the impact of Economic Growth on welfare a linear functional relationship of the form is established

$$
\ln E C G_{t}=f\left(Q \mathrm{CO}_{2} E_{t}, Q G E E_{t}, Q N O E_{t}, Q P C H E_{t}, \ln Q P C I_{t}\right)_{1}
$$

Linearizing Equation 1 gives:

$$
E C G_{t}=\beta_{0}+\beta_{1} Q C O_{2} E_{t}+\beta_{2} Q G E E_{t}+\beta_{3} Q N O E_{t}+\beta_{4} Q P C H E_{t}+\beta_{5} \ln Q P C_{2}
$$

$$
\ln E C G=\beta_{0}+\beta_{1} Q C O_{2} E_{t}+\beta_{2} Q G E E_{t}+\beta_{3} Q N O E_{t}+\beta_{4} Q P C H E_{t}+\beta_{5} \ln Q P C I_{t}+\mu_{t}
$$

Variables in the models are defined as follows: LNQGDP = economic growth (proxied by real growth in gross domestic product), $\mathrm{QCO}_{2} \mathrm{E}=$ carbon dioxide emission, $\mathrm{QGEE}=$ government education expenditure as a 
percentage of gross national income, $\mathrm{QNOE}=$ nitrous oxide emission, $\mathrm{QPCHE}=$ per capita health expenditure and QPCI = economic welfare (proxied by per capita income)

\section{Theories}

Theories considering welfare states provide an adequate framework for the understanding the key relationships between institutions and social spending and their effects on human welfare and poverty levels. In the examination of the relationship between economic growth and welfare, two approaches can be distinguished: structural approach which emphasizes the importance of structural-functional factors and the political-economic approach which lay emphasis of the roles of political factors in determining the welfare of the people in the country.

In the discussion of welfare, different theories have been offered. They include eco-efficiency theory which links economic efficiency with environmental efficiency. The main purpose is to identify and implement activities to enable production that is both economically more efficient and cleaner in order to create more values in the society (Daly, 1992). Eco-efficiency emphasizes on how to help individuals, companies, governments or other organizations in the society become more sustainable. It brings together the essential ingredients of economic and ecological progress which are necessary for economic prosperity to increase with more efficient use of resources without compromising environmental sustainability. But in the discussion of sustainability, indicators are essential in illustrating to policymakers and the public alike the relationship and trade-offs among the dimensions of sustainable development. However, capturing the dynamics of sustainable development and presenting them in terms of measurement indicators that could be unambiguously interpreted and easily communicated to policymakers for public policies remain a challenging task (WCED, 1987, Verfaillie and Bidwell, 2000).

There is also the traditional welfare theory designed to uncover the paradigm that lies behind traditional welfare theory to evaluate the further usefulness of that paradigm. It also assesses undercurrents within traditional welfare theory showing how they elucidate essential features of the underlying paradigm. With these goals, emphasis was further shift to the classical utilitarianism, neoclassical welfare theory and modern formulation of welfare. Utilitarianism and their critics argue that the greatest happiness criterion must subsume all other notions of social good. The essence of neoclassical welfare theory is that the performance of economic institutions can and should be judged according to whether they provide economic goods in quantities that accord with people's relative desires for those goods.

Well-being has been widely viewed as one of the most important aspects of people's lives both as individuals and as societies. However, despite unprecedented growth being experienced by some developing countries in the last decade, people do not necessarily feel better. As enunciated by Brekke and Howarth (2002). well-being which is often associated with happiness or satisfaction of life, is about having meaningful and worthwhile life, able to fulfill potentials. The discussion of well-being also draws on several reviews of literature, including Dally, (1992), Sen (1999), Stymne and Jackson (2000), Sardar, Islam and Clarke (2002), Lawn (2005), Schneider, Kallis and Martinez-Alier (2010), Posner and Costanza (2011), Fleurbaey (2015). While a number of countries and international organizations have already used (or are in the process of setting up) some measures of well-being, currently no nation or organization regularly and systematically collects a full spectrum of measures of subjective well-being. This state of affairs has led several researchers and to express the need for developing and systematically using national accounts of well-being in recent years (Sardar, Islam and Clarke, 2002, Posner and Costanza 2011). Fleurbaey (2015) also argued that countries should create ongoing assessments of well-being to complement existing economic indicators such as gross domestic product GDP, savings rates, consumer confidence and social indicators like crime rates, longevity; infant mortality rates which can help improve the quality of life in societies.

Discussions of well-being seek to consider other dimensions such as people's perceptions of social wellbeing or national quality of life; patterns and trends in physical and mental health; and alternative measures of progress. It is also concerned with how different qualities such as people's social welfare and social reforms, structure of economy, fiscal and structural reforms, innovation, research, innovative activities and coordination of industrial policies and transition to a socio-ecological model in the future affect personal and social wellbeing and influence territorial intelligence.

Wills and $\mathrm{Ng}$ (2012) carried out theoretical study on welfare economics and sustainable development and found that welfare maximization does not necessarily imply sustainable development, and sustainable development does not imply welfare maximization. However, welfare maximization requires sustainable development; sustainable development is necessary though not sufficient for welfare maximization. In this regard, the Organization for Economic Cooperation and Development (OECD) (2015) therefore posit that governments should lay much emphasis on all aspects of welfare: economic, environmental and social that would go a long way in promoting economic growth of a country. But Cracolici et al (2009) presented a different analytical framework for assessing spatial disparities among countries. The study combined economic and non-economic aspects of a country's performance in an integrated logical framework using simultaneous equation models. One of the interesting finding is the inability of most countries to turn higher education 
skills acquired by the citizens into greater economic performance over time. The study is of the view that accurate policies aiming at environmental care is highly desirable.

Ogboru and Anga (2015) adopted a theoretical approach in the evaluation of the effects of environmental degradation on Nigeria and its implication for sustainable economic development. The paper submitted that Nigeria has a national development policy objective of achieving rapid economic growth and improvement in individual welfare on a sustainable basis, economic instruments and incentives are required to propel this development process in the desired direction. Awan (2015) examined the relationship between environment and sustainable economic development and found that both developed and developing countries are responsible for environmental hazards as developed countries are using excessive resources to produce surplus goods for export while poor countries re exploiting their existing resources to feed their growing population and end poverty level.

Gowdy (2015) carried out a seminal work on the new welfare economics for sustainability. He emphasized the debate that has been going on over various definitions of sustainability which have been conducted within the framework of traditional welfare economics. He posited that equating per capita consumption with welfare contradicts empirical evidence suggesting that the link between happiness and wealth/income is relatively weak. He therefore concludes by saying that alternative approaches to measuring well-being are being developed and these have great potential to move the sustainability debate forward. Mazumdar (2010) found evidence that in the middle and low-income countries there is one-way causal relationship between the two phenomena, but only up to a certain level of income, after which growth and human development move independently. The results, as highlighted by the author, vary with respect to both the three different indicators of human development and the different income level clusters. In particular, for the low and middleincome countries human development precedes economic growth, that is, low social development implies low labour productivity and in turn low income.

\section{Results}

Table-1. LLC Group Unit Root Test.

\begin{tabular}{l|l|l|l}
\hline Order of integration & LLC t-Statistic & Probability & Conclusion \\
\hline $\mathrm{I}(\mathrm{O})$ & 1.21746 & 0.8883 & Non-stationaryat level \\
\hline $\mathrm{I}(1)$ & 2.43837 & 0.9926 & Non-stationary at first difference \\
\hline $\mathrm{I}(2)$ & 11.4068 & 0.0000 & Stationary at second difference \\
\hline
\end{tabular}

Table-2. Johansen's Test for Cointegration.

\begin{tabular}{l|l|l|l|l}
\multicolumn{5}{c}{ Table-2. Johansen's Test for Cointegration. } \\
\hline Hypothesized No. of CE(s) & Eigenvalue & Trace Statistic & Critical values. & Probability \\
\hline None $*$ & 0.513272 & 118.9584 & 95.75366 & 0.0005 \\
\hline At most 1 $*$ & 0.313170 & 72.15525 & 69.81889 & 0.0322 \\
\hline At most 2 & 0.280718 & 47.73682 & 47.85613 & 0.0513 \\
\hline At most 3 & 0.218897 & 26.31923 & 29.79707 & 0.1194 \\
\hline At most 4 & 0.120742 & 10.26107 & 15.49471 & 0.2512 \\
\hline At most 5 & 0.028764 & 1.897079 & 3.841466 & 0.1684 \\
\hline
\end{tabular}

Table-3. Johansen Cointegratiom test for economic growth and the environmental welfare determinants.

\begin{tabular}{l|l|l|l|l}
\hline Hypothesized No. of CE(s) & Eigenvalue & Trace Statistic & 0.05 Critical values. & Probability \\
\hline None & 0.224980 & 28.66103 & 29.79707 & 0.0672 \\
\hline At most 1 & 0.128195 & 12.09468 & 15.49471 & 0.1524 \\
\hline At most 2 & 0.047907 & 3.177367 & 3.841466 & 0.0747 \\
\hline
\end{tabular}

Table-4. Regression Results.

\begin{tabular}{l|l|l|l}
\hline Variables & Coefficient & t-statistic & Probability \\
\hline C & 23.66019 & 8.4124 & 0.0000 \\
\hline LnQPCI & 0.931475 & 11.8393 & 0.0000 \\
\hline QCO2E & -0.001128 & -0.4099 & 0.6833 \\
\hline QGEE & -6.006190 & -1.9868 & 0.0514 \\
\hline QNOE & -0.000360 & -1.4097 & 0.1636 \\
\hline QPCHE & 0.002361 & 2.7671 & 0.0074 \\
\hline
\end{tabular}

\section{Discussion}

The result in the table above table reveals the result of the Levin, Lin and Chu unit root test for multiple series, also employed in panel unit root testing. The results shows that as a group, the variables are neither stationary at level form nor at first difference. However, at the second difference, the variables become stationary. It is important to note that this result is expected, since most macro-economic and environmental 
time-series data are known to be non-stationary at level form, except for very cases where it occurs. Since some of our variables are non-stationary (i.e., at level form), we go further to carry out co integration test. The essence is to show that; although our variables are non-stationary series, the variables have a long term relationship or equilibrium between them. That is, the variables are co integrated. In Table 2, the Johansen test for co-integration has not returned a full rank because the probabilities of all the hypothesized cointegrated equations are not less than 0.05. Therefore, we make our conclusion using the first hypothesis that none of the variables are cointegrated. Since the probability there is less than 0.05 , we actually reject the hypothesis and therefore conclude that there is cointegration or long-run relationship among the exogenous variables as well as between them and the independent variable. Next, we will now check for the long-run relationship or the cointegration between our dependent variable and the environmental welfare determinants

In Table 3, as a contrast to a full rank which signifies that there is no cointegration between the dependent and the independent variables, we have a zero rank, which then implies that there is a long-run relationship between economic growth and the environmental welfare determinants.

The result presented in Table 4 reveal that as at the first quarter of 1999, i.e. at the beginning of this study, the Gross Domestic Product was about \#18.86 billion. Furthermore, over the quarterly period of 1999:1 to 2016:4, a \#1 increase in per capita income leads to an overall increase in GDP to the tune of No.93 billion. Now, still within the period under study, a $1 \%$ increase in carbon dioxide emission in Nigeria reduced GDP growth rate by $0.11 \%$. Also, still in the period under study, a $1 \%$ increase in quarterly government education expenditure shows a very high degree of negative responsiveness by economic growth by 6.0. Furthermore, a $1 \%$ increase in the nitrous oxide emission in the environment leads to a decline in the quarterly GDP growth rate by about $0.04 \%$. Finally, still within the quarterly period of 1999:1 to 2016:4, a $1 \%$ increase in per capita health expenditure of government on the citizens of the country increases the growth rate of GDP by about $0.24 \%$. This suggests that any attempt at increasing emissions in Nigeria will lead to a reduction in the environmental welfare as growth and other development indicators will be affected negatively. Also, since government education expenditure has a negative relationship with economic growth, there is a diversion of fund meant for education. Thus, further increase in expenditure on health and education should be closely monitored.

\section{Conclusion}

This study analyzed the relationship between economic growth and welfare in Nigeria and found hat essentially, there are a number of problems with the economic growth strategy. First, although economic growth is necessary for poverty reduction it is not sufficient, as growth alone cannot overcome the entire important factors that contribute to poverty. Although, in general, policies fostering economic growth facilitate poverty reduction, some types of growth clearly do not clearly improve welfare. Beside, the benefits of growth have often been concentrated, contrary to the need of them to be widely shared for growth to have the greater impact on the people. In view of the findings, there should be radical change of the economic system through restructuring, improving the social environment and abilities of the poor, investing in basic and technical education to raise the supply of skilled labour, improving social health care, encouragement of good governance. The governments can directly help those in need especially the vulnerable and most at risk, such as the elderly and people with disabilities in terms of monetary or food aid.

\section{References}

Abramowitz, M. (1981). Welfare quandaries and productivity concerns. In: thinking about growth. pp: 352377. Available from: https://doi.org/10.1017/cbo9780511664656.015.

Adelakun, A. (2011). For first time voters, change in motivation. The Punch Tuesday 19th April.

Awan, A.G. (2015). Relationship between environment and sustainable economic development: A theoretical approach to environmental problems. International Journal of Asian Social Sciences, 3(3): 741-761.

Brekke, K. A. \& Howarth, R. B. (2002). Status, growth, and the environment: Goods as symbols, Applied Welfare Economics, Cheltenham, U.K.: Edward Elgar.

Balami, D. H. (2006). Macroeconomic theory and practice. Maiduguri: Salawe Prints.

Cracolici, M.F., Cuffaro, M. \& Nijkamp, P. (2009). The measurement of economic, social and environmental performance of countries: A novel approach. Social Indicator Research, 95: 339-356. Available at: $10.1007 / \mathrm{s} 11205-009-9464-3$.

Central Bank of Nigeria (CBN), (2016). Statistical Bulletin, Abuja.

Daly, H. E. (1992). Allocation, distribution, and scale: Towards an economics that is efficient, just, and sustainable, Ecological Economics, 6: 185-193.

Fleurbaey, M. (2015). On sustainability and social welfare. Journal of Environmental Economics \& Management, 71: 34-53. Available at: https://doi.org/10.1016/j.jeem.2015.02.005.

Gowdy, J. (2015). Towards a new welfare economics for sustainability. Ecological Economics, 53(2): 21 1-222. Available at: https://doi.org/10.1016/j.ecolecon.2004.08.007

Howarth, R., Rosenwald, P. \& Rosenwald, J. (2012). Sustainability, well-being, and economic growth. Minding Nature, 5(2). 
Lawn, P. A. (2005). A theoretical foundation to support the index of sustainable economic welfare (ISEW), genuine progress indicator (GPI), and other related indexes. Ecological Economics, 44(3): 105-118.

Meadows, D. H., Randers, J. \& Meadows, D. L. (2004). Limits to growth: The 30-year update (White River Junction, VT: Chelsea Green Publishing.

Ng, Y.K. \& Wills, A. (2012). Welfare economics and sustainable development. Welfare Economics Journal, $1(6): 1-9$.

Neumayer, E. (1999). The ISEW: Not an index of sustainable economic welfare. Social Indicators Research 48(1): 77-101.

Ogboru, I. \& Anga, R.A. (2015). Environmental degradation and sustainable economic development in Nigeria: A theoretical approach. Research Journal of Economics, 3(6): 11-20.

OECD Council Meeting, (2015). Policies to enhance sustainable development.

Posner, S. M. \& Costanza, R. (2011). A summary of ISEW and GPI studies at multiple scales and new estimates for Baltimore City, Baltimore County, and the State of Maryland. Ecological Economics, 70: 1972- 1980.

Romer, P. (1990). Endogenous technological change. Journal of Political Economy, 98(5): 71-102.

Sardar, M., Islam, N. \& Clarke, M. (2002). The relationship between economic development and social welfare: A new adjusted GDP measure of welfare. Social Indicators Research, 57(2): 201-228.

Schneider, F., Kallis, G. \& Martinez-Alier, J. (2010). Crisis or opportunity? Economic DE growth for social equity. Journal of Cleaner Production, 18(2): 511-518.

Sen, A. K. (1999). Development as freedom. New York: Anchor Books.

Stymne, S. \& Jackson, T. (2000). Intragenerational equity and sustainable welfare. Ecological Economics, 33(2): 219-236.

Verfaillie, H.A. \& Bidwell, R. (2000). Measuring eco-efficiency: A guide to reporting company performance: World Business Council for Sustainable Development (WBSCD).

World Commission on Environment and Development (WCED), (1987). Our common future. New York: Oxford University Press, 43.

World Bank, (2015). World development report. Washington, D.C.: World Bank. 